\title{
How Jokes Change and May Be Changed: Simplifying, Transforming and Revealing
}

\section{Christie Davies}

University of Reading, United Kingdom

j.c.h.davies@reading.ac.uk

\begin{abstract}
Many excellent jokes can pose potential difficulties for tellers and listeners since they require considerable knowledge of the subject of the joke and have a long and elaborate narrative structure such that only a very skilled joke-teller can do justice to them. In a democratic, fastmoving, plural, urban world such features can create problems since they mean that on a particular occasion when jokes are being told some of the listeners may miss the point of the joke and others will feel inhibited from telling a joke. Jokes with seemingly pointless endings may likewise disappoint the broad masse, who like clear, well structured jokes with a strong resolution and who may be bored by one that disappears into nonsense. Each of these points will be considered in turn, partly from an analytical point of view and partly in relation to empirical observations of how jokes in the English language have evolved in the course of the twentieth century.
\end{abstract}

Keywords: jokes, ethnic, social class, Jewish, Poles

\section{Streszczenie}

Jak dowcipy się zmieniają i jak można je zmieniać - uproszczenia, przekształcenia i dopowiedzenia

Wiele ze świetnych dowcipów może potencjalnie sprawić problemy, zarówno opowiadajacym je jak i stuchaczom, gdyż wymagają znacznej wiedzy z dziedziny opowiadanego żartu. Co więcej, dowcipy często posiadaja dtuga i wyszukana strukture narracyjna, do tego stopnia, że tylko osoby posiadajace wyjątkowe umiejętności opowiadania sa w stanie $w$ petni oddać ich puentę. W zurbanizowanym świecie, gdzie panuje demokracja i pluralizm, a życie plynie szybko, takie cechy dowcipów moga być źródtem kłopotów, ponieważ oznaczaja one, że w pewnych sytuacjach stuchacze moga nie zrozumieć dowcipu, co może zniechęcić innych. Dowcipy z najwyraźniej bezsensownymi zakończeniami moga podobnie rozczarować masowego odbiorce, który woli jasne, dobrze skonstruowane dowcipy z mocnymi puentami $i$ którego może znudzić dowcip rozpływający się $w$ nonsensie. Każde z tych twierdzeń będzie omówione $w$ kolejności, zarówno ze względów badawczych, jak $i$ w zwiazku z empirycznymi obserwacjami procesu ewolucji dowcipów anglojęzycznych wXX wieku. 
Słowa kluczowe: dowcip, etniczny, klasa społeczna, żydowski, polski

\section{The historical simplifying of the stupidity joke}

Many early twentieth century British, American and Australian jokes about the alleged stupidity of the Irish (Davies 1990, 1998) consisted of long and detailed tales which when written down in a printed joke book could be half a page or even a page long. The teller would, with greater or less accuracy, put on an Irish brogue when telling them, which also meant that the best raconteurs of these jokes might well be Irishmen, some of whom could switch back and fore between two or three different Irish accents (Dubliner, County Antrim, Kerryman, generic culchee, West Briton etc. when telling a joke. Given also that the ability to tell a good story, to use wordplay skilfully and to be witty are qualities valued in Ireland, clever Irish joketellers of jokes about the Irish might well use jokes to achieve esteem and popularity among their British, Americans and Australian associates. As in the case of the Newfoundlanders, this enabled the Irish to "own" the jokes (Davies 2002a: 135-159) and by their skill with words to demonstrate that the Irish stupidity script was merely a script, not a description of reality (Raskin 1985: 180). The jokes often had jab-lines and referred to other observable Irish traits such as the use of repartee to undermine anyone else's authority, a fondness for alcohol and a belligerent mode of drunken comportment (Davies 1998: 107-122 ), a devotion to a rigourist version of Roman Catholicism, employment as peasant farmers at home in Ireland, wielding a pick in the building trade in all the English speaking countries or as dumb Irish cops or mendacious manipulators of municipal machine politics in the United States (Davies 1990: 156-159). They were thus in both their very language and their detailed social references very genuinely Irish jokes. Studying them begins almost to overlap with the program of work Chłopicki $(2001,2004)$ has proposed for longer humorous narratives in English. The examples given below well demonstrate these points:

(1) A young Irishman whose family was scattered pretty well over the English-speaking portions of the globe emigrated to America. Soon after his arrival in New York he paid a visit to the Bronx Zoo. He halted in front of a cage containing one of the largest kangaroos in captivity. After watching the curious creature for some time in an awed silence, he hailed a keeper:

"What's that thing?" he asked. 
"That", said the keeper in his best professional manner, "is a marsupial, a mammal that carries its young in a pouch on its breast, lives on roots and herbs, can jump twenty feet at one leap, is able to knock a human being down with a kick from either hind leg, and is a native of Australia".

"For the love of Hiven!" cried the Irishman, bursting into tears. "me sisther's married to wan of thim" (Cobb 1923: 173-74; also Greenway 1972: 280).

(2) There was once an Irishman who sought employment as a diver, bringing with him his native enthusiasm and a certain amount of experience. Although he had never been beneath the water, he had crossed an ocean of one variety and swallowed nearly an ocean of another. But he had the Hibernian smile, which is convincing and the firm chanced to be in need of a new man. And so on the following Monday morning Pat hid his smile for the first time in a diving helmet.

Now the job upon which the crew to which Pat had attached himself was working in comparatively shallow water and Pat was provided with a pick and told to use it on a ledge below in a manner with which he was already familiar.

Down he went with his pick and for about fifteen minutes nothing was heard from him. Then came a strong, determined deliberate pull on the signal rope indicating that Pat had a very decided wish to come to the top. The assistants pulled him hastily to the raft and removed his helmet.

"Take off the rest of it", said Pat.

"Take off the rest of it?"

"Yes", said Pat. "Oi'll worruk no longer in a dark place where Oi can’t spit on me hands". (Patten 1909 :227).

(3) At the Observatory they had engaged a new night porter. He was an Irishman. During his first night on duty he watched one of the professors fixing a large telescope on its stand. He was very mystified. Nothing like this had ever been heard of in his remote village. Presently the professor began to focus his telescope and move it about till he got it into position. At that moment a shooting star darted across the sky, falling rapidly.

"Begob", said the porter staring at the professor, "but that's foine shootin, glory be!" (Further Sunbeams 1924: 122 also Copeland and Copeland 1939: 728).

(4) An Irishman had died and had a lot of floral offerings on his coffin. The deceased had begun his career at street work digging sewers and cellars and so forth but he afterwards became a rich contractor. The widow since her rise to wealth had put on an awful lot of society airs and she walked into the room where the coffin lay with a very haughty mien. The apartment was full of flowers and mourners. A prominent floral piece was an anchor. The widow gazed upon it. The idea that some of her cast-off friends were trying to disconcert her by calling up memories of her former days came into her mind. Turning to the assembled company she asked: "Who the divil sint that pick?" (Ernst, 1927: 88). 
(5) At a closely contested municipal election in New York the Tammany ticket seemed in grave danger. Accordingly steps were taken. Scarcely had the polls opened when a group of trained and experienced repeaters marched into a down-town voting place.

"What name?" inquired the election clerk of the leader of the squad, who was red-haired and freckled and had a black eye. The young gangster glanced down at a slip of paper in his hand to refresh his memory.

"Isadore Mendelheim", he said then.

“That's not your real name, and you know it!", said a suspicious challenger for the reform ticket.

"It is me name", said the repeater, "and I'm goin' to vote under it - see?"

From down the line came a voice:

"Don't let that guy bluff you, Casey. Soitinly your name is Mendelheim!"

(Cobb 1923: 87; also Cerf 1945: 120).

All this changed in the late 1950s and early 1960s when the Americans switched from telling stupidity jokes about the Irish to telling stupidity jokes about the Poles. The new jokes are much shorter, sometimes one liners and in the main simple question and answer riddle jokes. They are told in standard American English without any use of Polish words or idioms or a Polish accent (Davies and Chłopicki 2004). They do not ascribe any observed and established traits to the Poles; there are few references to alcohol, Catholicism or distinctive occupations. The Italians or the Portuguese can be substituted for the Poles in American jokes with very little difficulty for they are generic jokes about the many ethnic groups making up an allegedly dirty and stupid white-American lower class. They are not jokes about Poles but about proles (Davies 1990: 67-74, Davies 2002a: 151-171). When the new stupidity jokes spread to Britain and Australia, they were promptly applied to the Irish. The more recent British jokes about the Irish are very different from the earlier ones as can be seen from the examples below:

(6) Irish secretary to boss:

“After I've typed your letter, I'll type the carbon copy and then I'll go to lunch"

(Chambers 1981: 33).

(7) Voice on Irish telephone answering machine: "Speak when you hear the green light". (Chambers 1980: 30).

(8) How do you tell an Irish word-processor?

Typ-Ex on the screen. (British brand name for typists' correcting fluid) 
(9) Then there was the Irish tube train driver who was sacked for overtaking. (ibid.)

(10) Why did they stop making ice in Ireland?

They forgot the recipe.

(11) Why are Irish tea breaks only four minutes long?

If they were longer, you'd have to retrain the workers.

The new jokes can be told more quickly, getting to the punch line faster, which means that in any social gathering more jokes can be told in a given time (Uttley 1971/1973: 344-357) and more people get to tell a joke. This democratisation of joke telling is reinforced by the fact that the jokes are easier to tell. The teller does not need to do accents, to tell a good story, to invent or remember jab lines. The Irish can no longer play a leading role in telling them and have almost ceased to own them. The latest examples are often merely using the Irish as the butts of a generic international joke about stupidity, though it must be added that the older tradition of joking about the Irish has survived alongside the new style jokes and new old style jokes are still being invented.

\section{Transforming elephant jokes into Irish jokes}

It is convenient at this point to switch to a completely different possible use of the Irish stupidity script and to show how it can be used to clarify and restructure the so-called elephant jokes (Dundes and Abrahams 1975; Elefanten Buch 1964). It can be argued that elephant jokes are not fully fledged jokes but pieces of nonsense that mimic jokes. They can, however, as demonstrated below be turned into jokes with a stronger structure, a story and a punch line by locating them within a conversation between two Irish people. The way in which the nature and structure of the joke changes when it is converted from an elephant quasi-joke riddle into an Irish joke is best illustrated by means of an example:

(12) Q Why does an elephant wear red socks?

A Because his yellow ones are in the wash.

The second line is an arbitrary nonsensical reply to the question. One of the following could, without losing anything, easily replace it:

(13) A2 To match his painted toenails. 
A3 Because purple ones would be too conspicuous.

Any ending that has as its mechanism a move from the question of why an elephant should wear socks at all to a reply concerning why they are a particular colour will do. They are rather similar to the pointless riddles told by children which an adult cannot guess because the link between question and answer is arbitrary and only known to the child who has acquired the riddle by rote memory. Such items might work better if placed into a longer text with an elaborate and sophisticated construction. One can imagine an elephant joke being inserted in the famous conversation between Alice and Humpty Dumpty (Carroll- 1965: 171-175) and then rounded off by the latter with a profoundly funny comment about elephants and logic. However, standing on their own, these riddles about prodigious podial protections for pachydermous pedestrians do seem rather woolly.

Elephant jokes may well have a very limited appeal and circulation. As a piece of pure speculation rooted in nothing more than intuition grounded in experience, I imagine the exchangers of elephant jokes to be young, ingenuous, middle class, substance-smoking herbivores dressed in designer label, unisex dungarees who like silly, playful, innocent nonsequiturs of all kinds. ("When we are together we always laugh a lot, sometimes at nothing at all because - well I don't really know why but it is always kind of funny."). By contrast, it is difficult to imagine such jokes being told by a group of "good old boys" in a bar just back from a hunting trip in a red pick-up truck with a gun rack and hound dogs. The elephant jokes do not have enough structure, enough regularity, enough playing with aggression to satisfy this other group (c.f. Martin 1981: 175 on music). However, it is possible to turn the elephant joke cited above into an Irish joke with a familiar, well-known script that will provide a clear script opposition, a target, a situation and a transparent logical mechanism - i.e. into a well-made narrative joke:

(14) Mrs. Murphy took her little boy Aloysius to the Zoological Gardens in Dublin to see the elephants. He noticed that one of them was wearing red socks.

"Why is that", he asked his mother?

“To be sure I don't know at all”, replied Mrs. Murphy, "let me ask the keeper of the elephants, Mr. Behan. That's him standing over there behind the elephants with a big shovel and a bucket".

"Brendan", she shouted, "Why is the elephant wearing red socks?"

“Ah", replied Brendan, "that's a good question. I think it must be because his yellow ones are in the wash". 
What had been a question set to baffle a listener is now a conventional ethnic joke about stupidity. The internal conversation can be orally delivered using a conventional stage-Irish accent and Mr. Behan is carrying that traditional Irish implement, a shovel; there is even a hint as to its unmentionable purposes in this case. The use of the conversation with Mr. Behan is to give the absurdity and stupidity of the joke a firm location, namely inside Mr. Behan's head.

Here the changes described in the earlier part of this account have been reversed. It should now be apparent that is easy to transform any stripped-down riddle joke in this way by treating it not as a slick and swift question and answer joke to be told in its original form but as the basis of a do-it-yourself kit for assembling a longer narrative joke. Most riddle jokes and very short narrative jokes can be expanded in this fashion. The transformation is rooted in the way we remember jokes anyway. Even a narrative joke is not committed to memory by a listener for telling on another occasion. Rather the listener remembers the general run of the story plus the punchline. When he or she comes to retell it, he or she reinvents the joke on the spot with new and possibly fake-local references, new jab lines and ,according to choice, either maintaining the illusion that it is akin to a true story or rendering it even more ludicrous. It means that even in a world of short, simplified, rapid-turnover jokes, there is still a place for the skilled and creative joke teller.

In the case of the elephant jokes the move towards minimalism had gone too far, to the point where the necessary as well as the auxiliary elements in the jokes had been stripped away. However, it is a reversible process as has been indicated and even where there are no preexisting examples of a narrative joke to use as a model they can be manufactured to order. It was not difficult to invent the scene involving Mrs Murphy, her young son, Aloysius and Keeper Behan.

\section{Jokes about blonde girls and Essex girls}

In the 1999s, there arose a large new cycle of short riddle jokes in the United States, the Blonde Girl jokes, about women whose main characteristic was a reckless promiscuity but who were also completely stupid. These short jokes later became popular throughout the world. Very few of them were longer narrative jokes. Troy C. Belding, the compiler of one of the longest collections, 'The Complete Set of Blonde Jokes' on $25^{\text {th }}$ January $1993^{1}$ broke his collection of 441 jokes down into 394 Question and Answer jokes, and only 47 other kinds. Of the latter only 29 were narrative jokes. None of them demands the kind of knowledge provided by education or indeed any degree of intellectual insight. They are indeed "jokes for blondes" - 
quick, easy democratic jokes requiring no inventive nor narrative skills - the ultimate in unsophisticated jokes.

The British version of these jokes is in general similar and there must have been an exchange of jokes between the two countries. There is an urban legend that the jokes were exchanged during quiet times in the markets by dealers in commodities and shares who were in constant business contact across the Atlantic by phone.

Interestingly the British version of the jokes takes on a local form, the Essex girl jokes. Essex is the flat muddy county to the North-East of London that provides much of the semiskilled, semi-educated lower white-collar female workforce of London's offices. Many of them are the daughters and granddaughters of Cockneys displaced from East London by slum clearance. They speak "Estuary English", a variety of lower class South-Eastern English that sounds as if it has Cockney ancestry. Essex girl jokes are both social class jokes and jokes that have been given a locality. Blondes do not live anywhere in particular but Essex girls live in Essex. As such, they lend themselves to being turned into narrative jokes that can be told in a particular way, more or less skilfully. They can be told in mock Estuary English or in the stageCockney which acts in Britain as a generic form of lower-class speech for humorous purposes (Davies 2002b: 168-169). They also take on local qualities and make local references which probably only make sense within Britain itself and they are clearly British inventions:

(15) What do Essex Girl and Dagenham ${ }^{2}$ man have in common?

They both spend a lot of time in Fords. (see also The Official Essex Girl Joke Book)

(16) How does an Essex Girl turn off the light after sex?

She slams the door of the Cortina. (The Official Essex Girl Joke Book)

(17) Wayne and Tracey are in a restaurant.

Wayne: "Do you fancy coq au vin?"

Tracey: "Nah. I fink sex in a transit is tacky". (see also Don 1991: 25)

(18) Voice on phone: “'allo Tracey. It's me".

Tracey: “"oo are you".

Voice: "Don't you remember. I 'ad you in the pub car park last night".

Tracey: “Er, was it The Red Lion, The Turk’s Head or The Royal Oak ?” (see also Don 1991: 34 )

(19) An Essex girl and an Irishman are in a pub. The Essex girl notices something strange about the Irishman's wellies. She says to the Irishman, 
" 'scuse me mister, I ain't being funny nor nuffink, but why does one of your wellies have an L on it, and the uver one's got an R on it?"

The Irishman grins, puts down his pint of stout and says, "Well, in Ireland we are all a bit t'ick, you see. The one with the $\mathrm{R}$ is for me roight foot and the one with the $\mathrm{L}$ is for me lift foot." "Cor !" says the Essex girl, "so that's why me knickers 'ave got C\&A on the label"

(20) The map of Eastern England looks very like the back-end of a pig. East Anglia is one side of the rump, Kent is the other and Canvey Island occupies a very important position indeed ${ }^{5}$

The Essex girl jokes do not provide a full reversion to the long detailed narrative jokes of an earlier time but they do indicate that the snappy international jokes of the internet can be placed once more in a distinctly local and narrative context.

\section{Making Jewish jokes more widely accessible by adding information}

One genre of the jokes that has retained its antecedents and its narrative qualities is the Jewish joke but even here changes have been made as the jokes have spread to a wider, often gentile audience. In Britain and America the changes have also been necessary if the jokes are to continue to circulate among a younger generation of Jews, many of whom are secular, assimilated and only speak English. Here we can see another technique being used to introduce jokes to a broader, plural audience which may not have the knowledge resources necessary to understand a particular genre of jokes. The alternative technique to simplifying the jokes (which in some cases might destroy them) is to incorporate the information necessary to an understanding of the jokes into the telling of the joke itself using the device of internal narration. This is a particularly apt way of adapting Jewish jokes so that they may be enjoyed by a gentile audience who will probably be ignorant of some of the elements from Jewish life, culture, religious observance and taken for granted comic scripts necessary to a full understanding of the joke. Again, this is best demonstrated by means of an example. Let us begin with a joke told to the author (Davies 2002a :69) by a Polish and Yiddish speaking Rabbi working in Chicago, America whose ancestors had originally come from Galicia, which at that time had been part of Austria in the Austro-Hungarian Empire.

(21) Three Hasidim are boasting about their Rebbes.

The first says "My Rebbe is so great. One Friday afternoon he was in his carriage an hour's ride from home, with just an hour to Shabbes, when a terrible storm arose with hail and thunder and lightning, and they couldn't move. The Rebbe got up and said "Storm to the right and storm to the left, and clear in the 
middle". And a miracle happened: the storm continued to his right and to his left, but a clear path opened up in front of them and they got home just in time for Shabbes.

The second says, "That's nothing. One Friday afternoon my Rebbe was in his carriage an hour's ride from home, with just an hour to Shabbes, when a terrible fog came up. You couldn't see your hand in front of your face. They couldn't see which way was home. The Rebbe got up and said "Fog to the right, and fog to the left, and clear in the middle. And a miracle happened: the fog continued to the right and to the left, but a path of visibility opened in front of them and they could drive through the fog and get home just in time for Shabbes.

The third says "That's nothing. One Friday afternoon my Rebbe was in his carriage two hours' ride from home, with just one minute to Shabbes, and the Rebbe got up and said "Shabbes to the right and Shabbes to the left and Chol (any non-sacred day) in between". And a miracle happened ; it was Shabbes to his right and Shabbes to his left but in the middle it was still Friday and he managed to get home without violating the Shabbes (Eastern Europe traditional but alive in Chicago, America in 2000; see Davies 2002a: 69).

The teller had originally known the joke in Yiddish but he told it in English. Even so it retains distinctive Jewish terms such as Rebbe (Heb. 'Rabbi') and Shabbes for Sabbath. It has a highly particular context, namely the amusement with which most Polish Jews would have regarded the credulity of groups of Hasidim concerning the miraculous powers of a particularly pious religious leader. It also requires the listener to know of the strict rules observed by Orthodox Jews generally that forbid travelling on the Sabbath, restrictions that did not apply on non-sacred days. It is a joke with a somewhat limited appeal for the goyim. However, in modern Britain and America Jewish jokes are regularly adapted and reshaped so that they may find a wider audience. Thus, the older joke above has emerged in a new form that is comprehensible to everyone, Jewish, Protestant, or Roman Catholic alike:

(22) A Protestant minister, a Roman Catholic priest and a rabbi were talking about the miracles they had experienced. The minister said, "I was once travelling on a plane when all the engines cut out one by one and we were falling out of the sky. I prayed and prayed to God and then one of the engines began to work again and we were able to land safely. It was a miraculous response to my prayers". The priest then said, "Once I was walking along the edge of a cliff when I stumbled and fell down towards the beach. I cried out "St. Anthony save me, I'm lost" and to my amazement I landed on a holidaymaker's trampoline. The rabbi listened with interest to his colleagues' stories and said, "I was walking to synagogue one Saturday, when I saw a large bundle of bank notes lying at the side of the road and as you know I'm not allowed to carry money on the Sabbath. So I prayed and prayed and suddenly for a hundred yards around me it was Tuesday" (Jewish, British and American 1990s Davies 2002: 69). 
In the new version of the joke about miracles that familiar trio in British and American Jewish jokes - the minister, the priest and the rabbi - have replaced the three credulous Chasidim. The minister and the priest are unimportant - it does not really matter what their miracles are, provided they can be contrasted with the one finally provided by the conventionally practical and hard-headed rabbi. The crucial reason that they must be there is so that the rabbi can tell them in conversation that "as you know I'm not allowed to carry money on the Sabbath". In this way, a vital piece of information is conveyed indirectly by the joke-teller to the listener without being tediously didactic or undercutting the punch line. The gentiles inside the joke to whom the information is provided by the rabbi are thus surrogates for the gentiles listening to the joke. To instruct the listeners directly would be tedious and condescending but the narrative device used is painlessly instructive. The final joke is less Jewish than the original in its setting and its language but it does nonetheless remain a distinctively Jewish joke, though one that is now amenable to non-Jewish interpellated jab-lines. It has not been torn up from its roots but it is no longer growing in an enclosed field. It is this kind of adaptiveness that has underpinned the unique success of Jewish jokes.

\section{Conclusion: A social as well as a linguistic phenomenon}

What can be seen here is a general phenomenon that is as much social as linguistic. It is probably true for all urban, industrial post-industrial countries and especially those in which television and the internet have become dominant. Jokes have become shorter and less demanding of the intellect of the listener and the skill of the teller. Jokes have come to require less local cultural knowledge and where this is required it is explicitly conveyed within the joke. It is one more aspect first of globalisation and the trend towards homogeneity.

The contribution of television has been indirect, for many of these jokes could not be told on television, particularly in Britain and the United States where a very strict politically correct censorship prevails in broadcasting (Davies 2004). Rather television has meant dumbing down and simplifying and speeded up consumption by a mass audience. This has affected the style of jokes told because conventional attention spans have been shortened.

Yet jokes still remain a key vehicle for popular creativity (Davies 2004; Kuipers 2001). The jokes on the internet were not invented by script-writers nor by those who collected and posted them. They are the jokes of the people in the same sense as were the political jokes told in Poland under socialism. Narrative jokes have survived, the art of joke-telling has survived and the use of jokes as an exploration of the forbidden has survived. The arrival and 
multiplication of the riddle joke has led to an enormous growth in the total volume of jokes and a decline in the proportion of jokes that are narrative jokes. Nevertheless, the absolute number of narrative jokes may well have increased even though they have lost something of their richness of detail.

\section{Acknowledgements}

The text was first published in 2006 in At the Crossroads of Linguistic Sciences edited by Piotr Chruszczewski, Język a komunikacja 10. Kraków: Tertium; 349-382.

\section{Notes}

${ }^{1}$ Available at : (http://www.lysator.liv.se/jokes/blonde.html; see also http://www.humorsphere.com/sms/blondejokes.htm, and http://nser.itl.net/ future/GGirl.htm)

2 Dagenham is a big council housing estate to the East of London (Willmott 1963) of whose inhabitants provide the unskilled labour for the large Ford motor-car assembly plant there. To have sex in a Ford, particularly in a small, angular car like a Cortina within which having sex would be uncomfortable and probably hasty implies promiscuity. This is why Tracey says "I fink sex in a transit is tacky" meaning "I think having sex in a van is crude, vulgar, tasteless, cheap." Wayne (male) and Tracey (female) are comic, generic, lower-class names, probably taken from Hollywood films. They are the equivalent of the late nineteenth century or Edwardian comic Cockney names 'arry (Harry, Henry) and 'arriett (Harriett).that often appeared in jokes and cartoons.

3 The Red Lion, The Turks Head and The Royal Oak are typical names of British public houses, places where alcohol is sold and consumed.

${ }^{4}$ Wellies $=$ wellington boots, short rubber boots worn on building sites; Nuffink = Essex Girl English for nothing, Uver = Essex English for other. T'ick = Irish pronunciation of thick, here: stupid; Similarly: Roight and $l i f t=$ right and left. $C \& A$ is a cheap department store that sells underwear and other clothes. It is popularly known as Coats and 'ats but here $C \& A$ has a rather coarser, indeed more fundamental meaning.

${ }^{5}$ Canvey Island is a small muddy tidal island in the Thames estuary on the Essex coast. A similar joke is told about Sheppey on the other side of the water (Pahl 1984: 189).

\section{References}

Carroll, Lewis (1965). The Works of Lewis Carroll. Feltham UK: Spring. 
Cerf, Bennett (1945) Laughing Stock. New York: Grosset and Dunlap.

Chambers, Gary (1980) The Second almost Complete Irish Gag Book. London: Star.

Chambers, Gary (1981) The Last almost Complete Irish Gag Book, London: Star.

Chłopicki, Władysław (2001) "Humorous and non-humorous stories: Are there differences in frame-based reception?". Stylistyka 10: Style and Humour; 59-78.

Chłopicki, Władysław (2004) "Are there cultural prototypes of humorous short stories?" [In:] Evelina Graur; Alexandru Diaconescu (eds.) Messages, Sages and Ages: Proceedings of the $1^{\text {st }}$ International Conference on British and American Studies Suceava University. Suceava: Editura Universităţii Suceava; 241-244.

Cobb, Irvin S. (1923) A Laugh a Day Keeps the Doctor Away. Garden City, NY: Garden City Publishing.

Copeland, Lewis, Faye Copeland (1939) 10,000 Jokes, Toasts and Stories. Garden City NY: Garden City Publishers.

Davies, Christie (1998) Jokes and their Relation to Society. Berlin: Mouton de Gruyter.

Davies, Christie (1990) Ethnic Humor around the World: A Comparative Analysis. Bloomington IN: Indiana UP.

Davies, Christie (2002a) The Mirth of Nations. New Brunswick, NJ: Transaction.

Davies, Christie (2002b) "Comic and Serious Patterns of Speech in Kipling’s Verse". Stylistyka XI, Stylistics and Poetics; 157-180.

Davies, Christie (2004) The Right to Joke. London: Social Affairs Unit.

Davies, Christie, Władysław Chłopicki (2004) "Dowcipy o Polakach w Ameryce - znamienny wytwór współczesnego społeczeństwa masowego". [In:] Piotr Chruszczewski (ed.) Aspekty wspótczesnych dyskursów. Series: Język a komunikacja 6 vol. 1, Kraków: Tertium; 59-77.

Don, Basil (pseud.) (1991) The Very Best of Essex Girl Jokes, London: Attica.

Dundes, Alan, Roger D. Abraham (1975) “On Elephantasy and Elephanticide.” [In:] Alan Dundes (ed.) Analytical Essays in Folklore. The Hague: Mouton; 192-205.

Elefanten Buch, Das [no indication of editor] (1964) Freiburg: Walter.

Ernst, Theodor R. (1927) Laughter: Gems of the World's Best Humor. New York:

Theodore R. Ernst.

Further Sunbeams [no indication of editor] (1924) London: Stanley Paul.

Greenway, John (1972) The Last Frontier. London: David-Poynter.

Kuipers, Giselinde (2001) Goede humor, slechte Smaak, Nederlanders over Moppen. 
Amsterdam: Boom.

Leigh, Ray, and Brent Wood, Brent (pseuds.) (1991) The Essex Girl Joke Book. London: Corgi Books.

Martin, Bernice (1981) The Sociology of Contemporary Culture Change. Oxford: Blackwell.

The Official Essex Girl Joke Book [no date of publication, no place of publication, no publisher; unpaginated].

Pahl, Raymond, Edward (1984) Divisions of Labour. Oxford: Blackwell.

Patten, William (1959) Among the Humorists and After Dinner Speakers. New York: P. F. Collier.

Raskin, Victor (1985) Semantic Mechanisms in Humor. Dordrecht, Reidel.

Uttley, Francis Lee (1971/73) “The Urban and Rural Jest.” Bealoideas, Nos. (39-41): 344-57.

Willmott, Peter (1963) The Evolution of a Community: A study of Dagenham after 40 years. London: Routledge and Kegan Paul. 